\title{
Extension of the northern distribution of Onychophora in the Brazilian Atlantic Forest
}

\author{
Gindomar Gomes Santana ${ }^{1}$ \\ Waltécio de Oliveira Almeida ${ }^{2}$ \\ Rômulo Romeu da Nóbrega Alves ${ }^{3}$ \\ Alexandre Vasconcellos ${ }^{4 *}$

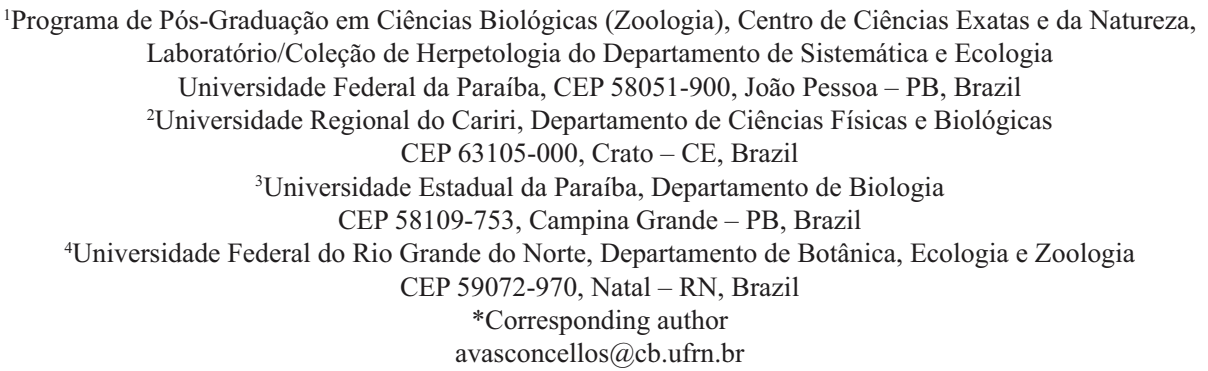

\section{Resumo}

Ampliação do limite norte de distribuição dos Onychophora na Mata Atlântica. Os Onychophora são invertebrados raros cuja posição filogenética é muito importante para a compreensão da origem e evolução dos artrópodes. Esses animais habitam predominantemente florestas úmidas e cavernas e possuem um tamanho que pode variar de $2,5-20 \mathrm{~cm}$. Neste estudo é registrada a ocorrência de um onicóforo pertencente ao gênero

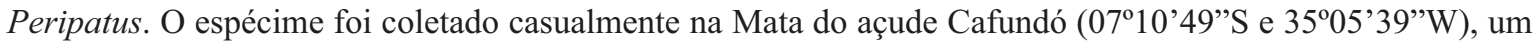
remanescente de Mata Atlântica situado no município de Cruz do Espírito Santo, Estado da Paraíba, Nordeste brasileiro, em junho de 2007. É o primeiro registro de um onicóforo para um remanescente florestal da Paraíba o que amplia a distribuição norte do táxon na Mata Atlântica litorânea, e representa a sétima ocorrência ao norte do Rio São Francisco. A formação de um banco de dados sobre os onicóforos da Mata Atlântica ao norte do São Francisco é imprescindível para categorizar adequadamente cada espécie quanto a sua distribuição, tamanho populacional, nível de isolamento, área e qualidade dos seus habitats.

Unitermos: Onychophora, distribuição, conservação da biodiversidade, Mata Atlântica, região Neotropical

\section{Abstract}

The Onychophora represent a rare group of invertebrates whose phylogenetic position is important in understanding the origin and evolution of the arthropods. These animals generally inhabit humid tropical forests and caves, and can vary in size from $2.5-20 \mathrm{~cm}$. The present study reports the occurrence of an onychophoran belonging to the genus Peripatus. The specimen was collected fortuitously in June, 2007, at Mata do Açude Cafundó $\left(07^{\circ} 10^{\prime} 49^{\prime \prime} \mathrm{S}\right.$ and $\left.35^{\circ} 05^{\prime} 39^{\prime \prime} \mathrm{W}\right)$, a remnant area of Atlantic Forest situated in the municipality of Cruz 
do Espírito Santo, Paraíba State, northeastern Brazil. This represents the first report of an onychophoran from a remnant forest area in Paraíba, extending the northern distribution of this taxon, and is only the seventh report of an onychophoran in an Atlantic Forest remnant north of the mouth of the São Francisco River. A data bank will be needed in order to adequately document the distributions, population sizes, degrees of isolation, and habitat quality of known species of onychophorans from this sector of the Atlantic Forest.

Key words: Onychophora, distribution, biodiversity conservation, Atlantic Forest, Neotropical region

The Onychophora represent a rare group of invertebrates that can vary in size from $2.5-20 \mathrm{~cm}$ (Newslands and Ruhberg, 1979). The phylogenetic position of these animals is important for understanding the origin and evolution of the arthropods (Monje-Nágera, 1995; Almeida et al., 2003). Onychophorans generally inhabit caves and humid tropical forests; in the latter they can be found in the leaf litter, inside (or on) rotting tree trunks, inside bromeliads or abandoned termite nests, or in soil crevices (Vasconcellos et al., 2004). Onychophorans are predators of termites, cockroaches, isopods, worms, and other ground-dwelling invertebrates (Hamer et al., 1997).

Approximately 160 species belonging to 49 genera and two families of onychophorans (Peripatidae and Peripatopsidae) have been described worldwide (ITIS-Catalogue of Life, 2007), with 11 species known in Brazil from the states of Pará, Espírito Santo, Rio de Janeiro, Amazonas, Minas Gerais, Goiás, and Mato Grosso (Peck, 1975; Oliveira \& Wieloch, 2005). Vasconcellos et al. (2004 and 2006) reported the occurrence of Onychophora in eight humid forest areas in four states within the Caatinga (dryland) and Atlantic Forest biomes in northeastern Brazil.

The present study reports the occurrence of an onychophoran of the genus Peripatus that was fortuitously encountered in Mata do Açude Cafundó (07 $10^{\circ}$ '49"S and $35^{\circ} 05^{\prime} 39^{\prime}$ 'W), a remnant area of Atlantic Forest (731ha) belonging to the Companhia Usina São João situated in the municipality of Cruz do Espírito Santo, Paraíba State, northeastern Brazil. The female specimen was deposited in the terrestrial invertebrate collection of the Botany, Ecology, and Zoology Department of the Federal University of Rio Grande do Norte State, Brazil (collection number: CICB 414).

The specimen of Peripatus sp. was collected in a fall-trap set for reptiles and amphibians. The traps were placed in a forested area downstream from the Cafundó dam. This area of forest is well shaded with large trees, epiphytic bromeliads, and species of Heliconia (Heliconiaceae); a deep leaf litter layer is present and many large rotting tree trunks lie on the ground. The sandy clay soil there is flooded in some areas. The specimen of Peripatus sp. is $40.0 \mathrm{~mm}$ in length and $3.9 \mathrm{~mm}$ in width, respectively, and has 35 pairs of legs.

This represents the first report of an onychophoran from a remnant forest area in Paraíba State, extending the northern distribution of this taxon within the coastal Atlantic Forest (AF), and it is only the seventh reported occurrence of this invertebrate in the AF north of the mouth of the São Francisco River (Table 1).

Extensive clearing has reduced the northern-most extension of the AF into a thin archipelago of forest fragments, and it now has only $1.5 \%$ of its original cover (Silva and Casteletti, 2003). In general, onychophoran species have only limited dispersal capacity due to their low mobility and their vulnerability to dehydration, and they appear to be restricted to well-preserved areas of AF (Vasconcellos et al., 2004 and 2006). Even without precise typological descriptions of the specimens found in AF areas north of the São Francisco River, the high rates of forest loss and habitat fragmentation, together with the lack of legal protection for many forest fragments larger than $100 \mathrm{ha}$, place this taxon at great risk of regional extinction (Tabarelli et al., 2004).

Traditionally, biodiversity conservation measures in Brazil have been largely focused on conspicuous and/or "charismatic" taxa, especially those with closer phylogenetic ties to humans (such as mammals). Many of the conservation areas in Brazil were created using vertebrate species as flagship species. One of the few exceptions to this rule was the Tripuí Ecological Station, situated in the municipality of Ouro Preto, Minas Gerais State $\left(20^{\circ} 23^{\prime} 5^{\prime \prime} \mathrm{S}\right.$ and $\left.43^{\circ} 34^{\prime} 33^{\prime \prime} \mathrm{W}\right)$, created in 1978 and focusing on the preservation of the onychophoran Macroperipatus acacioi (Marcus \& Marcus). 
TABLE 1: List of Atlantic Forest remnants north of the São Francisco River with registered sighting of Onychophora. Adapted from Vasconcellos et al. (2004). $\mathrm{PB}=$ Paraíba; $\mathrm{PE}=$ Pernambuco; $\mathrm{AL}=$ Alagoas.

\begin{tabular}{|c|c|c|c|c|c|}
\hline Locality & State & City & Coordinates & $\begin{array}{c}\text { Area } \\
\text { (hectares) }\end{array}$ & $\begin{array}{l}\text { Altitude } \\
\text { (meters) }\end{array}$ \\
\hline Mata do Açude Cafundó (present study) & PB & $\begin{array}{c}\text { Cruz do Espírito } \\
\text { Santo }\end{array}$ & $\begin{array}{c}07^{\circ} 10^{\prime} 49^{\prime \prime} \mathrm{S} \text { and } \\
35^{\circ} 05^{\prime} 39^{\prime \prime} \mathrm{W}\end{array}$ & 731 & 260 \\
\hline Horto Floresta de Dois Irmãos & $\mathrm{PE}$ & Recife & $\begin{array}{c}08^{\circ} 00^{\prime \prime} 37.7^{\prime \prime S} \text { and } \\
34^{\circ} 56^{\prime} 31^{\prime \prime} \mathrm{W}\end{array}$ & 338 & 50 \\
\hline Reserva Biológica de Serra Negra & $\mathrm{PE}$ & Bezerros & $\begin{array}{c}08^{\circ} 11^{\prime} \mathrm{S} \text { and } \\
35^{\circ} 47^{\prime} \mathrm{W}\end{array}$ & 627 & 500 \\
\hline Parque Ecológico Vasconcelos Sobrinho & $\mathrm{PE}$ & Caruaru & $\begin{array}{c}08^{\circ} 22^{\prime} \mathrm{S} \text { and } \\
36^{\circ} 2^{\prime} \mathrm{W}\end{array}$ & 359 & 900 \\
\hline Reserva Biológica de Pedra Talhada & AL & Quebrangulo & $\begin{array}{c}09^{\circ} 15^{\prime} \mathrm{S} \text { and } \\
36^{\circ} 25^{\prime} \mathrm{W}\end{array}$ & 3.750 & 800 \\
\hline Estação Ecológica de Murici & AL & Murici & $\begin{array}{c}09^{\circ} 15^{\prime} \mathrm{S} \text { and } \\
35^{\circ} 51^{\prime} \mathrm{W}\end{array}$ & 6.116 & 500 \\
\hline APA Mata do Catolé & AL & Maceió & $\begin{array}{c}09^{\circ} 40^{\prime} \mathrm{S} \text { and } \\
35^{\circ} 44^{\prime} \mathrm{W}\end{array}$ & 5.415 & 10 \\
\hline
\end{tabular}

The elaboration of a data-bank by Hamer et al. (1997) gave substance to a campaign to protect $90 \%$ of the onychophoran species in South Africa. Likewise, the formation of a data bank of onychophorans from the Atlantic Forest north of the São Francisco River will be needed in order to adequately document the distribution, population sizes, degree of isolation, and habitat quality of the known species.

\section{Acknowledgements}

The authors would like to thank CAPES for the doctoral grant to Gindomar Gomes Santana, the Companhia Usina São João for access to their lands, and IBAMA (Collecting License: 133/06 - IBAMA/RAN).

\section{References}

Almeida, W. O.; Christoffersen, M. L.; Amorin, D. S.; Garraffoni, A. R. S.; Silva, G. S. 2003. Polychaeta, Annelida, and Articulata are not monophyletic: Articulating the Metameria (Metazoa: Coelomata). Revista Brasileira de Zoologia, 20 (1): 23-57.

Hamer, M. L.; Samways, M. J.; Ruhberg, H. 1997. A review of the Onychophora of South Africa, with discussion of their conservation. Annals of the Natural Museum, 38: 283-312.

ITIS-Catalogue of Life. 2007. Annual Checklist. Accessible at $<$ http://www.catalogueoflife.org/search.php $>$. Accessed on September 30, 2007.
Monje-Nájera, J. 1995. Phylogeny, biogeography and reproductive trends in the Onychophora. Zoological Journal of the Linnean Society, 114 (1): 21-60.

Newlands, G.; Ruhberg, H. S. 1979. Onychophora. In: Werger, M. J. A. (ed.). Biogeography and Ecology of Southern Africa, Part 2 (Monographiae Biologicae, vol. 31, part 2). Dr. W. Junk Publishers: The Hague, Dordrech, Netherlands, p.677-684.

Oliveira, I. S.; Wieloch, A. H. 2005. Macroperipatus machadoi sp. n. (Onychophora: Peripatidae) da Floresta Atlântica de Minas Gerais, Brasil. Lundiana, 6: 61-66.

Peck, S. B. 1975. A review of the New World Onychophora, with the description of a new cavernicolous species and genus from Jamaica. Psyche, 82: 341-358.

Silva, J. M. C.; Casteletti, C. H. M. 2003. Status of the biodiversity of the Atlantic forest of Brazil In: Galindo-Leal, C. \& Camara, I. G. (eds). The Atlantic Forest of South America: biodiversity status, threats, and outlook. Center for Applied Conservation Science and Island Press, Washington, USA, p.3-11.

Tabarelli, M.; Silva, J. C. M.; Gascon, C. 2004. Forest fragmentation, synergisms and the impoverishment of Neotropical forests. Biodiversity and Conservation, 13: 1419-1425.

Vasconcellos, A.; Almeida, W. O; Eloy, E. C. C. 2004. Onychophora de florestas úmidas do complexo mata atlântica do nordeste brasileiro e sua importância para conservação e estudos sistemáticos. In: Porto, K. C; Cabral, J. J. C. \& Tabarelli, M. (eds). Brejos de altitude em Pernambuco e Paraíba: História natural, ecologia e conservação. MMA, Brasília, Brasil, p.139-144.

Vasconcellos, A.; Almeida, W. O.; Souza, L. A. 2006. Onychophora in humid forests of northeastern Brazil. Brazilian Journal of Biology, 66 (1A): 186-189. 